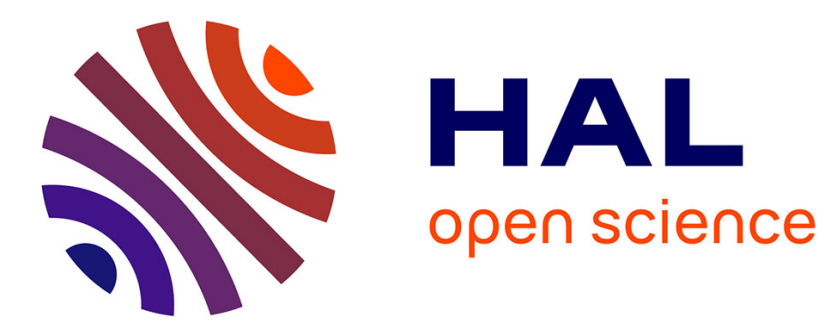

\title{
Isothermal Titration Calorimetry of Supramolecular Polymers
}

\author{
Alix Arnaud, Laurent Bouteiller
}

\section{To cite this version:}

Alix Arnaud, Laurent Bouteiller. Isothermal Titration Calorimetry of Supramolecular Polymers. Langmuir, 2004, 20 (16), pp.6858-6863. 10.1021/la049365d . hal-01696748

\section{HAL Id: hal-01696748 \\ https://hal.science/hal-01696748}

Submitted on 29 Aug 2020

HAL is a multi-disciplinary open access archive for the deposit and dissemination of scientific research documents, whether they are published or not. The documents may come from teaching and research institutions in France or abroad, or from public or private research centers.
L'archive ouverte pluridisciplinaire HAL, est destinée au dépôt et à la diffusion de documents scientifiques de niveau recherche, publiés ou non, émanant des établissements d'enseignement et de recherche français ou étrangers, des laboratoires publics ou privés. 


\title{
Isothermal titration calorimetry of supramolecular
}

\author{
polymers
}

\author{
Alix Arnaud, Laurent Bouteiller*
}

Laboratoire de Chimie des Polymères, UMR 7610, Université Pierre et Marie Curie, 4 place Jussieu 75252 Paris cedex 05, France.

\begin{abstract}
A method to characterize the self-association of supramolecular polymers by isothermal titration calorimetry (ITC) has been designed. Association constants in the range $10^{4}$ to $10^{\circ} \mathrm{dm}^{3}$ mol $^{-1}$ have been successfully determined from the heat exchange occurring when a supramolecular polymer solution is injected into a calorimetric cell containing pure solvent. Very good agreement with literature values has been obtained. Compared to other techniques (such as NMR or FTIR spectroscopy), the use of ITC presents several advantages: (i) the enthalpy of association is obtained together with the association constant from the same experiment, (ii) the measurements can be performed in almost any solvent, and (iii) systems with higher association constants can be characterized.
\end{abstract}

\section{Introduction}

Supramolecular polymers are chains of small molecules held together through reversible non-covalent interactions. ${ }^{.14}$ This reversibility is responsible for the appearance of new properties, as compared to those of usual covalent polymers. For instance, the molar mass of supramolecular polymers depends on concentration, solvent polarity and temperature. Thus, the best way to characterize the length of a supramolecular polymer is to measure the association constant $\left(\mathrm{K}_{\mathrm{a}}\right)$ of the interaction involved. Of course, potentially useful properties in dilute solutions are obtained only if the interaction is strong enough, 
typically $\mathrm{K}_{\mathrm{a}}>10^{6} \mathrm{dm}^{3} \mathrm{~mol}^{-1} .^{5.7}$ In the case of supramolecular polymers, such large association constants have mostly been determined indirectly by fluorescence techniques, with the help of model compounds.$^{8.9}$ It is thus desirable to adapt other techniques for this purpose. The aim of the present paper is to show that isothermal titration calorimetry (ITC) is perfectly suited to this problem.

ITC is widely used by biochemists and supramolecular chemists to characterize interacting systems..$^{10-16}$ The usual procedure is to titrate a solution of compound A placed in the calorimetric cell, by aliquots of a solution of compound B placed in an automated syringe. The exchanged heat is measured and reveals quantitative information about the interaction between A and B. Self-assembling mono-component systems can also be studied by ITC, but with a different procedure: a concentrated solution of the selfassociated compound is placed in the syringe and injected into the cell containing pure solvent. If the final concentration is low enough, the supramolecular assemblies are dissociated and the exchanged heat is characteristic of the dissociation event. This procedure has been used to measure the CMC of low molecular weight surfactants,,$^{1718}$ to study amphiphilic polyelectrolytes,${ }^{19}$ to derive the partition coefficient of solutes in lipid vesicules, ${ }^{20}$ and to measure the heat of dilution of non-ideal solutions..$^{21}$ In principle, this procedure can also be used in the case of supramolecular polymers, but no experimental demonstration has been reported yet.

The experimental system chosen to test the present procedure is a bis-urea based supramolecular polymer EHUT (Chart 1). This compound has been shown to reversibly self-assemble by hydrogen bonding in low polarity solvents, where it forms long wire-like structures..$^{722}$ In chloroform, the association is moderate, so that the association constants have been previously measured by infrared spectroscopy. ${ }^{23}$ This system (EHUT in chloroform) thus allows a quantitative assessment of the characterization of supramolecular polymers by ITC. In toluene, the association of EHUT is much stronger, which makes it possible to test the limits of this characterization technique. 
Chart 1. Structure of EHUT.<smiles>[R]NNC(=O)Nc1cc(NC(=O)N[R])ccc1C</smiles>

EHUT

\section{Experimental Section}

The solutions of EHUT (Chart 1) in chloroform (resp. toluene) were prepared at room temperature, under stirring for at least one day (resp. one week). The solvents (analytical grade) were used as received, except $\mathrm{CDCl}_{3}$, which was dried on molecular sieves.

Heats of dissociation were measured using a MicroCal VP-ITC titration microcalorimeter. The sample cell $\left(1.435 \mathrm{~cm}^{3}\right)$ was filled with pure solvent. A relatively concentrated EHUT solution in the same solvent was placed in a $0.295 \mathrm{~cm}^{3}$ continuously stirred $(310 \mathrm{rpm})$ syringe. A first $2 \mu \mathrm{L}$ aliquot was injected, without taking into account the observed heat, to remove the effect of solute diffusion across the syringe tip during the equilibration period. Subsequent aliquots of the solution ( 2 to $10 \mu \mathrm{L}$ ) were automatically injected into the sample cell every 200s, until the syringe was empty.

The uncertainty of the parameters reported in Table 1 was evaluated by fitting each experimental curve separately instead of all curves simultaneously (see part 3).

\section{Theory}

Scheme 1. Association equilibria involved in the formation of a supramolecular polymer $\left(\mathrm{M}_{1}=\right.$ monomer, $\mathrm{M}_{\mathrm{n}}=$ oligomer of degree of polymerization $\mathrm{n}$ ).

$$
\mathrm{M}_{1}+\mathrm{M}_{1-1} \stackrel{K_{\mathrm{n}} \mathrm{n} \geq 2}{=} \mathrm{M}_{\mathrm{n}}
$$

Self-association model. The self-association of supramolecular polymers can be described by the infinite set of equilibria mentioned on Scheme 1. Most systems studied so far have been shown to follow an isodesmic model, such that $K_{n}=K$ for $n \geq 2 . .^{24}$ However, cooperative ${ }^{23252.26}\left(K_{2}<K=K_{n}, n>2\right)$ or anti- 
cooperative $^{27}\left(K_{2}>K=K_{n}, n>2\right)$ systems have also been reported. We will thus consider the more general model with 2 constants: a dimerization constant $\left(K_{2}\right)$ and an oligomerization constant $\left(K=K_{n}, n>2\right)$. Within this model, the concentration of all supramolecular chains of degree of polymerization $n\left(C_{n}=\left[M_{n}\right]\right)$ can be expressed by applying the mass action law.

$$
C_{n}=K_{2} K^{n-2}\left(C_{1}\right)^{n}
$$

If the formation of cyclics is neglected, conservation of mass yields a third degree equation

$$
\mathrm{K}\left(\mathrm{K}-\mathrm{K}_{2}\right) \mathrm{C}_{1}^{3}+\left(\not \mathrm{K}_{2}-\not \mathcal{K}-\mathrm{K}^{2} \mathrm{C}_{0}\right) \mathrm{C}_{1}^{2}+\left(1+\not \mathrm{KC}_{0}\right) \mathrm{C}_{1}-\mathrm{C}_{0}=0
$$

from which the free monomer concentration $\left(C_{1}\right)$ can be determined, if $K_{2}, K$ and the overall concentration $\left(\mathrm{C}_{0}\right)$ are known. ${ }^{25}$ Through eq (1), the whole molecular weight distribution can then be determined.

Exchanged heat. At the beginning of an experiment, pure solvent is placed in the calorimetric cell of volume $\mathrm{V}_{0}$, and a solution of supramolecular polymer of total solute concentration $\mathrm{C}_{0}^{\mathrm{s}}$ is placed in the syringe. Let $\mathrm{C}_{\mathrm{n}}^{\mathrm{s}}$ be the concentration of supramolecular chains of $\mathrm{DP}_{\mathrm{n}}=\mathrm{n}$ in the syringe:

$$
C_{0}^{s}=\sum_{n=1}^{\infty} n C_{n}^{s}
$$

When $\mathrm{i}$ injections of volume $\Delta \mathrm{V}_{\mathrm{i}}$ have occurred, the total volume injected is

$$
V_{i}=\sum_{j=1}^{i} \Delta V_{j}
$$

and the total solute concentration in the cell is $C_{0}^{c}(i)$. Let $C_{n}^{c}(i)$ be the concentration of supramolecular chains of $\mathrm{DP}_{\mathrm{n}}=\mathrm{n}$ in the cell, after the $\mathrm{i}^{\text {th }}$ injection:

$$
C_{0}^{c}(i)=\sum_{n=1}^{\infty} n C_{n}^{c}(i)
$$

Because of the total-fill nature of the cell, each injection acts to drive liquid out of the cell. Consequently, the concentration in the cell is given by eq $(6) .^{28}$ 


$$
C_{0}^{c}(i)=C_{0}^{s} \frac{V_{i}}{V_{0}}\left(1-\frac{V_{i}}{2 V_{0}}\right)
$$

The heat exchanged during the $\mathrm{i}^{\mathrm{in}}$ injection of the supramolecular polymer solution into the cell $\left(\mathrm{Q}_{\mathrm{os}}(\mathrm{i})\right)$ is the sum of two terms:

$$
Q_{\text {obs }}(i)=\Delta Q(i)+Q_{\text {dil }}
$$

$\Delta Q(i)$ results from the dissociation of supramolecular chains into shorter chains (according to Scheme1). $\mathrm{Q}_{\text {dit }}$ takes into account both the mechanical heat related to the flow of the solution (which is independent of i), and the heat of dilution of solutes. This heat of dilution does not involve dissociation, and can be considered to be independent of $i$, if the concentration in the syringe is so low that non-ideality effects are negligible." $\Delta \mathrm{Q}(\mathrm{i})$, which corresponds to the injection of volume $\Delta \mathrm{V}_{\mathrm{i}}=\mathrm{V}_{\mathrm{i}}-\mathrm{V}_{\mathrm{i}-1}$, can be expressed as

$$
\Delta \mathrm{Q}(\mathrm{i})=\mathrm{Q}(\mathrm{i})-\mathrm{Q}(\mathrm{i}-1)+\frac{\Delta \mathrm{V}_{\mathrm{i}}}{\mathrm{V}_{0}}\left[\frac{\mathrm{Q}(\mathrm{i})+\mathrm{Q}(\mathrm{i}-1)}{2}\right]
$$

where $Q(i)$ is the heat exchanged when a supramolecular polymer solution of volume $V_{i}$ and concentration $\mathrm{C}_{0}^{s}$ is injected into the cell containing pure solvent. The last term in eq (8) takes into account the displaced volume which overflows the cell, but contributes partially to the heat measured ${ }^{28}$ The heat Q(i) corresponds to the dissociation of supramolecular chains when the concentration of a solution is reduced from $\mathrm{C}_{0}^{3}$ (in the syringe) to $\mathrm{C}_{0}^{\mathrm{C}}(\mathrm{i})$ (in the cell). It can be conveniently evaluated by considering the fictitious process of first diluting the solution from concentration $\mathrm{C}_{0}^{5}$ to infinite dilution, where only monomers are present, and then concentrating back to $\mathrm{C}_{0}^{\mathrm{C}}(\mathrm{i})$.

$$
Q(i)=Q(i)_{C_{0}^{3} \rightarrow 0}+Q(i)_{0 \rightarrow C_{0}^{c}(i)}
$$

These hypothetical heats are related to the molar enthalpies of association corresponding to dimerization $\left(\Delta \mathrm{H}_{2}\right)$ and oligomerization $(\Delta \mathrm{H})$ (Scheme 1 , with $\mathrm{n}=2$ or $\mathrm{n}>2$ respectively):

$$
Q(i)_{C_{0}^{a} \rightarrow 0}=-\Delta H\left(\sum_{n=3}^{\infty}(n-2) C_{n}^{s} V_{i}\right)-\Delta H_{2}\left(\sum_{n=2}^{\infty} C_{n}^{s} V_{i}\right)
$$




$$
Q(i)_{0 \rightarrow C_{0}^{c}(0)}=\Delta H\left(\sum_{n=1}^{\infty}(n-2) C_{n}^{c}(i) V^{\prime}\right)+\Delta H_{2}\left(\sum_{n=2}^{\infty} C_{n}^{c}(i) V^{\prime}\right)
$$

$V_{i}{ }^{\prime}$ is a hypothetical volume such that the amounts of solutes fictitiously diluted and concentrated back are identical:

$$
\mathrm{C}_{0}^{5} \mathrm{~V}_{1}=\mathrm{C}_{0}^{\mathrm{c}}(\mathrm{i}) \mathrm{V}^{\prime}
$$

Combining eqs (1) and (9) to (12) yields the following expression:

$$
\mathrm{Q}(\mathrm{i})=-\Delta \mathrm{HK}_{2} \mathrm{KV}_{\mathrm{i}}\left[\frac{\left(\mathrm{C}_{1}^{3}\right)^{3}}{\left(1-\mathrm{KC}_{1}^{3}\right)^{2}}-\frac{\mathrm{C}_{\mathrm{d}}^{3}\left(\mathrm{C}_{1}^{\mathrm{c}}(\mathrm{i})\right)^{3}}{\mathrm{C}_{0}^{\mathrm{c}}(\mathrm{i})\left(1-\mathrm{KC}_{1}^{\mathrm{c}}(\mathrm{i})\right)^{2}}\right]-\Delta \mathrm{H}_{2} \mathrm{~K}_{2} \mathrm{~V}_{i}\left[\frac{\left(\mathrm{C}_{1}^{3}\right)^{2}}{1-\mathrm{KC}_{1}^{3}}-\frac{\mathrm{C}_{0}^{3}\left(\mathrm{C}_{1}^{\mathrm{c}}(\mathrm{i})\right)^{2}}{\mathrm{C}_{0}^{\mathrm{c}}(\mathrm{i})\left(1-\mathrm{KC}_{1}^{\mathrm{C}}(\mathrm{i})\right)}\right]
$$

which is then introduced in eqs (8) and then (7). Finally, it is convenient to normalize the measured heat by the amount of solute injected:

$$
\tilde{Q}_{o b s}(i)=\frac{Q_{o b s}(i)}{C_{0}^{s} \Delta V_{i}}
$$

Consequently, 5 unknown constants $\left(\mathrm{K}_{2}, \mathrm{~K}, \Delta \mathrm{H}_{2}, \Delta \mathrm{H}\right.$ and $\left.\mathrm{Q}_{\text {dif }}\right)$ are necessary to completely describe such a calorimetric experiment. Figure 1 shows the calculated evolution of $\overline{\mathrm{Q}}_{\mathrm{abs}}(\mathrm{i})$ for reasonable values of these constants. The curves have a sigmoïdal shape. The magnitude of the step is directly related to the $\Delta \mathrm{H}$ value, whereas $\Delta \mathrm{H}_{2}$ has a minor effect (Figure 1). The position of the step with respect to the concentration axis is mainly related to the $\mathrm{K}$ value, while $\mathrm{K}_{2}$ influences only the slope of the curve (Figure 2). 


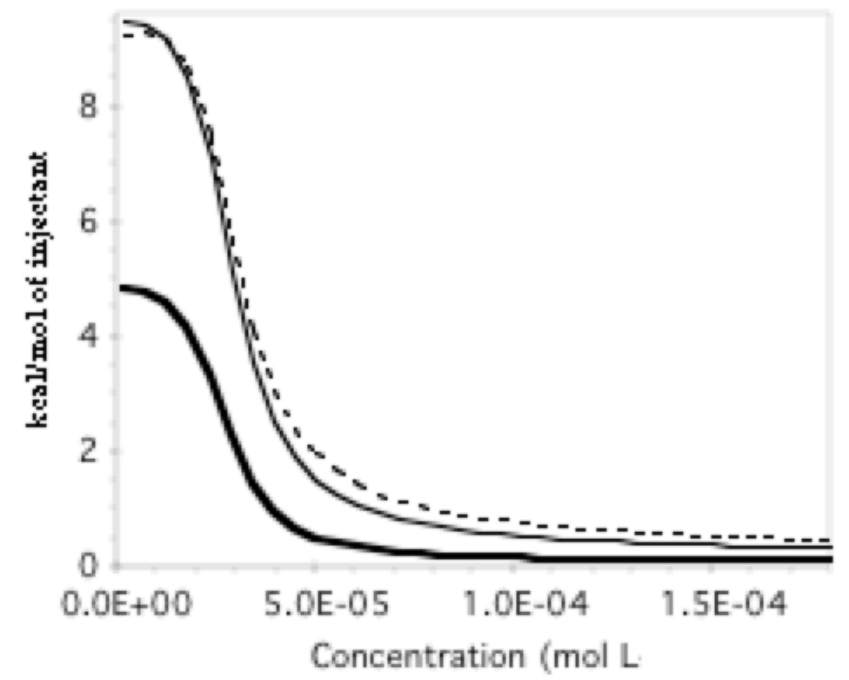

Figure 1. Theoretical enthalpograms calculated for $\Delta \mathrm{H}_{2}=\Delta \mathrm{H}=-42 \mathrm{~kJ}$ mol ${ }^{-1}$ (plain curve), $\Delta \mathrm{H}_{2}=-42 \mathrm{~kJ} \mathrm{~mol}^{-1}$ and $\Delta \mathrm{H}=-21 \mathrm{~kJ}^{\mathrm{mol}}{ }^{-1}$ (bold curve), $\Delta \mathrm{H}_{2}=-4 \mathrm{~kJ} \mathrm{~mol}^{-1}$ and $\Delta \mathrm{H}=-42 \mathrm{~kJ}$ mol $^{-1}$ (dotted curve). $\mathrm{K}_{2}=500 \mathrm{dm}^{3} \mathrm{~mol}^{-1}$, $\mathrm{K}=30000 \mathrm{dm}^{3} \mathrm{~mol}^{-1}$ and $\mathrm{Q}_{\mathrm{wil}}=0$ for all curves.

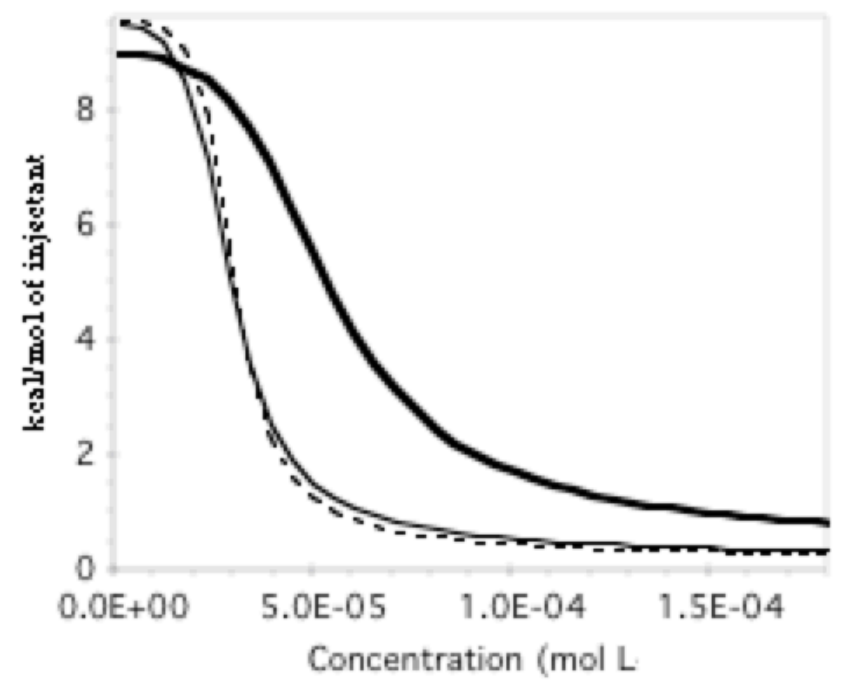

Figure 2. Theoretical enthalpograms calculated for $\mathrm{K}_{2}=500 \mathrm{dm}^{3} \mathrm{~mol}^{-1}$ and $\mathrm{K}=30000 \mathrm{dm}^{3} \mathrm{~mol}^{-1}$ (plain curve), $\mathrm{K}_{2}=500 \mathrm{dm}^{3} \mathrm{~mol}^{-1}, \mathrm{~K}=15000 \mathrm{dm}^{3} \mathrm{~mol}^{-1}$ (bold curve), $\mathrm{K}_{2}=250 \mathrm{dm}^{3} \mathrm{~mol}^{-1}$ and $\mathrm{K}=30000 \mathrm{dm}^{3} \mathrm{~mol}^{-1}$ (dotted curve). $\Delta \mathrm{H}_{2}=\Delta \mathrm{H}=-42 \mathrm{~kJ} \mathrm{~mol}^{-1}$ and $\mathrm{Q}_{\mathrm{du}}=0$ for all curves. 
Fit of experimental results. Starting with arbitrary values for the 5 constants $\left(\mathrm{K}_{2}, \mathrm{~K}, \Delta \mathrm{H}_{2}, \Delta \mathrm{H}\right.$ and $\left.\mathrm{Q}_{\mathrm{din}}\right)$, it is possible to calculate the free monomer concentrations $C_{1}^{s}$ and $C_{1}^{c}(i)($ eq (2)), and then the normalized heat (eqs (13), (8), (7) and (14)). Minimization of the distance between the experimental curve and the theoretical curve, with a standard non-linear curve fitting routine, should afford reasonable values for the 5 constants. However, two difficulties are encountered. Firstly, it is not possible to obtain the full sigmoïdal curve in a single experiment, except for very cooperative systems. This results in a large uncertainty for the constants deduced. Consequently, we prefer to run at least 4 experiments with starting concentrations $\left(\mathrm{C}_{0}^{s}\right)$ differing by a factor of 2 , and to perform the non-linear curve fitting procedure simultaneously on the 4 experimental curves (see part 4). Secondly, even this procedure yields unreliable values for $\Delta \mathrm{H}_{2}$, because of the very small influence of this parameter (Figure 1). We checked that imposing an arbitrary value to $\Delta \mathrm{H}_{2}$, and then adjusting the additional parameters to fit the experimental data, yields parameter values that lie within experimental uncertainty. Consequently, we impose $\Delta \mathrm{H}_{2}=\Delta \mathrm{H}$, and perform the simultaneous curve fitting of the 4 curves. In this case, there are 7 constants: $\mathrm{K}_{2}, \mathrm{~K}, \Delta \mathrm{Hand}$ $\mathrm{Q}_{\text {dill }}$ to $\mathrm{Q}_{\text {dil }}$ which correspond to the heat of dilution for each measurement. Thus, experiments performed at a single temperature cannot yield a value for $\Delta \mathrm{H}_{2}$. However, this parameter is accessible through van't Hoff analysis of variable temperature experiments (see part 4).

\section{Results and Discussion}

Confrontation with FTIR data. Figure 3 shows the heat flow curve obtained when a 6mM EHUT solution in $\mathrm{CDCl}_{3}$ is incrementally injected into pure $\mathrm{CDCl}_{3}$ at $20^{\circ} \mathrm{C}$. The process is endothermic, in agreement with the fact that hydrogen bonds are dissociated during the dilution. The peaks decrease in intensity throughout the experiment, because the increasing EHUT concentration in the cell limits the extent of dissociation during the following injections. Integration of the heat flow peaks yields the enthalpograms presented in Figure 4 and 5 (5 experiments were performed with a different EHUT concentration in the syringe). The expected sigmoïdal shape is obtained, and it can be seen that the lowest concentration experiment $(3 \mathrm{mM})$ reveals a plateau followed by a decrease. The plateau illustrates the fact 
that the first injections lead to the full dissociation of supramolecular chains into free monomers. This plateau is not visible in the high concentration experiments. However, the high concentration experiments are informative, because they reveal the leveling off of the curve at the end of the experiment. Two approaches were evaluated to fit the data. In a first simple approach, the 5 curves were simultaneously fitted with the isodesmic model described in part $3\left(\mathrm{~K}_{2}=\mathrm{K}\right)$, with $\mathrm{K}, \Delta \mathrm{H}$ and $\mathrm{Q}_{\text {dill }}$ to $\mathrm{Q}_{\text {dils }}$ as adjustable constants (Figure 4). The quality of the fit is extremely poor, which is in agreement with previous results showing that the self-association of EHUT is not an isodesmic process..$^{23}$ In a second approach, the 5 curves were simultaneously fitted with the cooperative model described in part 3, with $\mathrm{K}_{2}, \mathrm{~K}, \Delta \mathrm{H}$ and $\mathrm{Q}_{\text {dinl }}$ to $\mathrm{Q}_{\text {dis }}$ as adjustable constants (Figure 5). The quality of the fit over this large concentration range is very satisfactory. The values of the constants obtained are listed in Table 1, together with the values previously determined by FTIR spectroscopy (first line in Table 1). The agreement between the two techniques is very good considering that (i) unlike the FTIR experiment, it is not possible to perform the ITC experiment in strict water-free conditions, and (ii) different assumptions inherent to each technique have been made. The coherence of these data validates the present procedure. The advantage of the ITC experiment is that enthalpy (and thus entropy) of association are simultaneously obtained, without running the measurement at several temperatures.

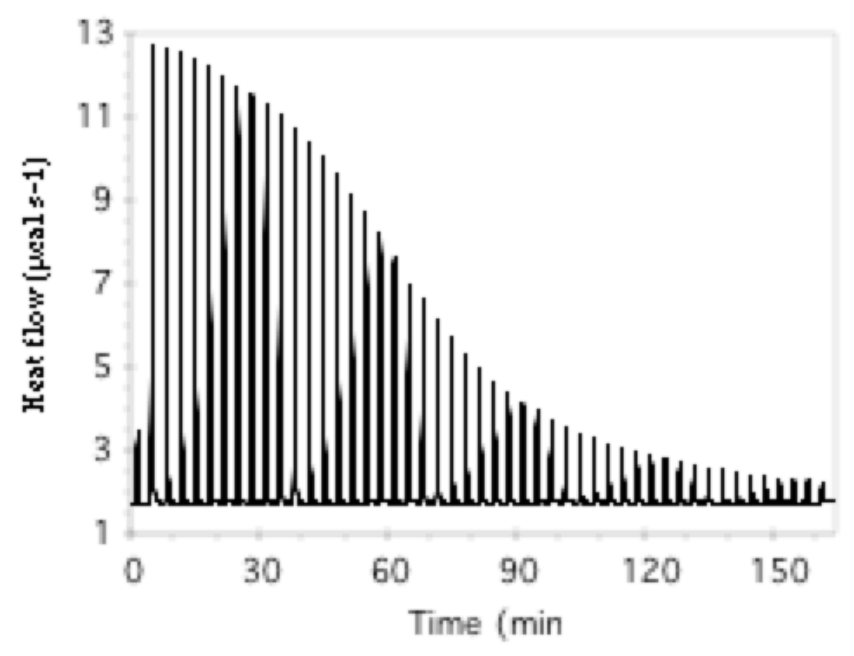


Figure 3. Heat effect produced by injecting $6 \mu \mathrm{L}$ aliquots of a $6 \mathrm{mM} \mathbf{E H U T}$ solution in $\mathrm{CDCl}_{3}$ into $\mathrm{CDCl}_{3}$ $\left(\mathrm{T}=20^{\circ} \mathrm{C}\right)$.

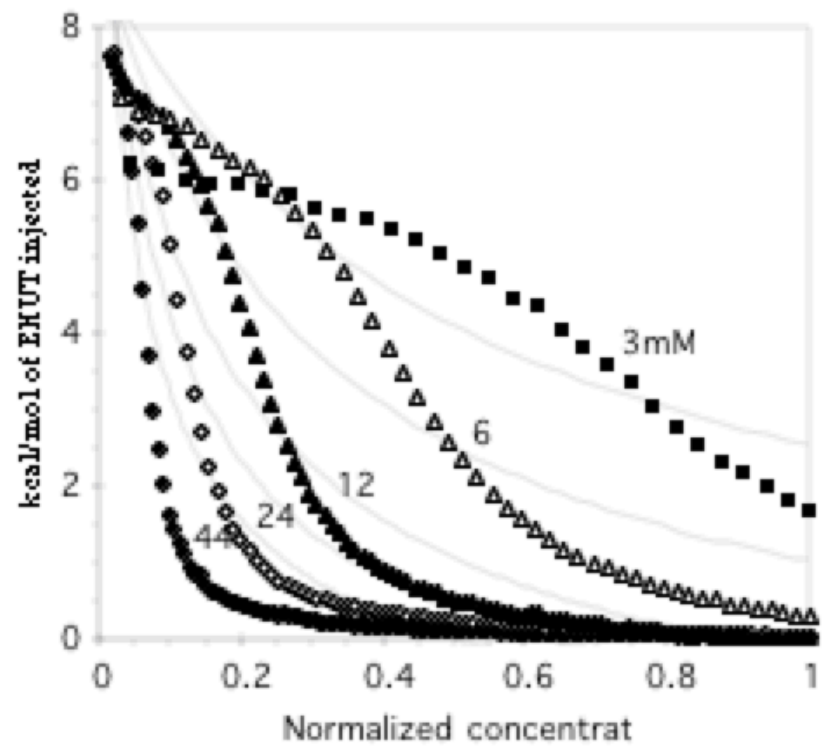

Figure 4. Enthalpograms of $44 \mathrm{mM}, 24 \mathrm{mM}, 12 \mathrm{mM}, 6 \mathrm{mM}$ and $3 \mathrm{mM}$ EHUT solutions in $\mathrm{CDCl}_{3}$ versus concentration normalized by the final cell concentration $\left(\mathrm{T}=20^{\circ} \mathrm{C}\right)$. The plain curves are the "best" fits obtained with the isodesmic model $\left(\mathrm{K}_{2}=\mathrm{K}\right)$ presented in part 3 .

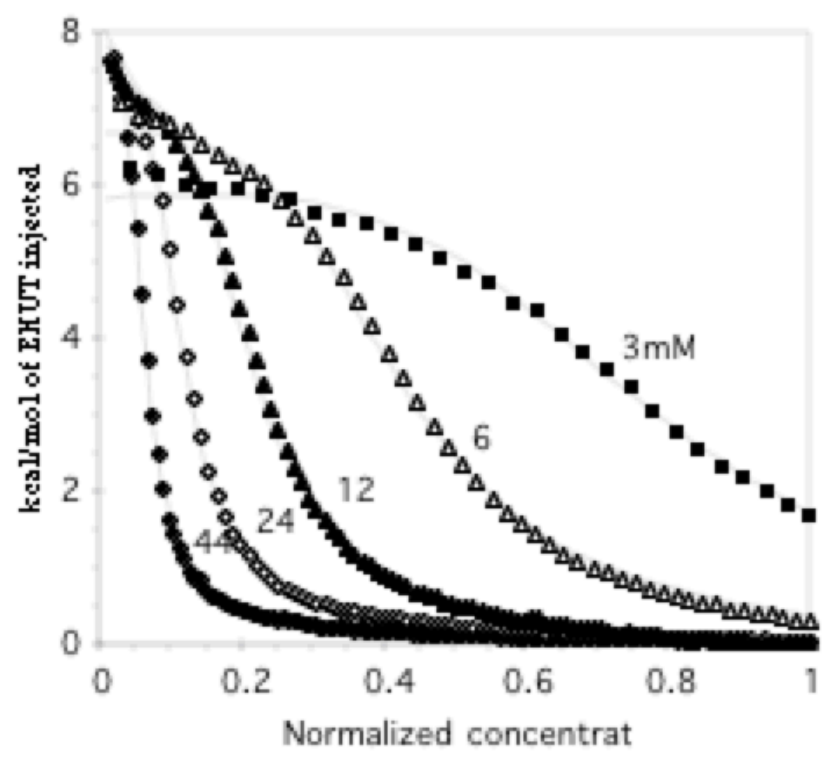


Figure 5. Enthalpograms of $44 \mathrm{mM}, 24 \mathrm{mM}, 12 \mathrm{mM}, 6 \mathrm{mM}$ and $3 \mathrm{mM}$ EHUT solutions in $\mathrm{CDCl}_{3}$ versus concentration normalized by the final cell concentration $\left(T=20^{\circ} \mathrm{C}\right)$. The plain curves are the fits obtained with the cooperative model $\left(\mathrm{K}_{2}<\mathrm{K}\right)$ presented in part 3 and the parameter values reported in Table 1.

Table 1. Thermodynamic parameters determined by ITC, for solutions of EHUT.

\begin{tabular}{|c|c|c|c|c|c|c|c|c|}
\hline solvent & $\mathrm{T}_{\mathrm{a}}^{\mathrm{a}}$ & $\mathrm{K}_{2}{ }^{\mathrm{b}}$ & $\mathrm{K}^{\mathrm{c}}$ & $\mathrm{K} / \mathrm{K}_{2}{ }^{\mathrm{d}}$ & $\mathrm{K}^{2} / \mathrm{K}_{2}{ }^{\mathrm{e}}$ & $\Delta \mathrm{H}^{\mathrm{f}}$ & $\Delta \mathrm{H}_{2 \mathrm{vH}} \mathrm{g}$ & $\mathrm{C}_{\mathrm{O}^{\mathrm{h}}}^{\mathrm{n}}$ \\
\hline$C D C l_{3}$ & $R T$ & $21^{i}$ & $1400^{i}$ & $70^{i}$ & $1.010^{5 i}$ & - & - & - \\
\hline $\mathrm{CDCl}_{3}$ & 20 & 57 & 1700 & 30 & $5.110^{4}$ & -36 & - & $44 / 24 / 12 / 6 / 3$ \\
\hline $\mathrm{CHCl}_{3}$ & 10 & 74 & 2500 & 34 & $8.610^{4}$ & -33 & -16 & $44 / 24 / 12 / 6 / 3$ \\
\hline $\mathrm{CHCl}_{3}$ & 20 & 58 & 1700 & 29 & $4.810^{4}$ & -35 & -16 & $44 / 24 / 12 / 6 / 3$ \\
\hline $\mathrm{CHCl}_{3}$ & 30 & 54 & 1100 & 20 & $2.110^{4}$ & -36 & -16 & $44 / 24 / 12 / 6$ \\
\hline $\mathrm{CHCl}_{3}$ & 40 & 37 & 680 & 18 & $1.210^{4}$ & -37 & -16 & $44 / 24 / 12 / 6$ \\
\hline toluene & 40 & 430 & 28500 & 66 & $1.910^{6}$ & -48 & - & $2 / 1 / 0.5 / 0.25$ \\
\hline \multicolumn{9}{|c|}{ Temperature, in ${ }^{\circ} \mathrm{C}$. } \\
\hline \multicolumn{9}{|c|}{${ }^{\circ}$ Dimerization constant, in $\mathrm{dm}^{3} \mathrm{~mol}^{-1}$. Uncertainty $\pm 30 \%$. } \\
\hline \multicolumn{9}{|c|}{ ' Oligomerization constant, in $\mathrm{dm}^{3} \mathrm{~mol}^{-1}$. Uncertainty $\pm 10 \%$. } \\
\hline \multicolumn{9}{|c|}{${ }^{d}$ Measure of the cooperativity along the supramolecular chain. } \\
\hline \multicolumn{9}{|c|}{. Association constant between long oligomers, in $\mathrm{dm}^{3} \mathrm{~mol}^{-1}$. } \\
\hline \multicolumn{9}{|c|}{ Enthalpy of oligomerization, in $\mathrm{kJ}^{\mathrm{f}} \mathrm{mol}^{-{ }^{-1}}$. Uncertainty $\pm 10 \%$. } \\
\hline \multicolumn{9}{|c|}{ \& Enthalpy of dimerization, determined by van’t Hoff analysis, in $\mathrm{kJ}^{\mathrm{mol}}{ }^{-1}$. Uncertainty $\pm 30 \%$. } \\
\hline \multicolumn{9}{|c|}{${ }^{\mathrm{n}}$ Concentrations used, in $10^{-3} \mathrm{~mol} \mathrm{dm}{ }^{-3}$. } \\
\hline Dete & . & 11 & & & & & & \\
\hline
\end{tabular}




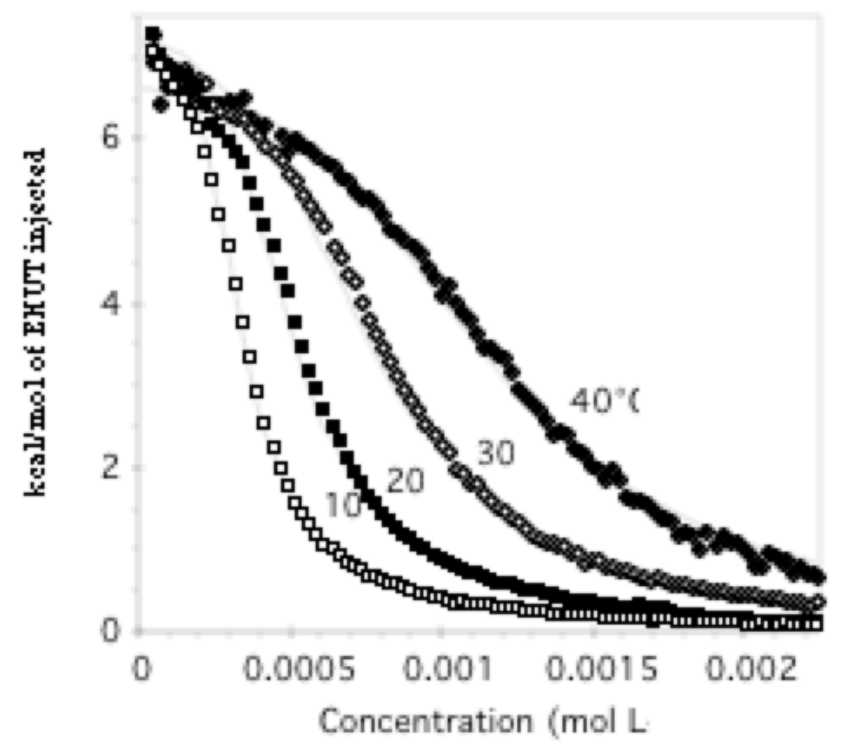

Figure 6. Enthalpograms of a $12 \mathrm{mM}$ EHUT solution in $\mathrm{CHCl}_{3}$, at $\mathrm{T}=10^{\circ} \mathrm{C}, 20^{\circ} \mathrm{C}, 30^{\circ} \mathrm{C}$ and $40^{\circ} \mathrm{C}$.

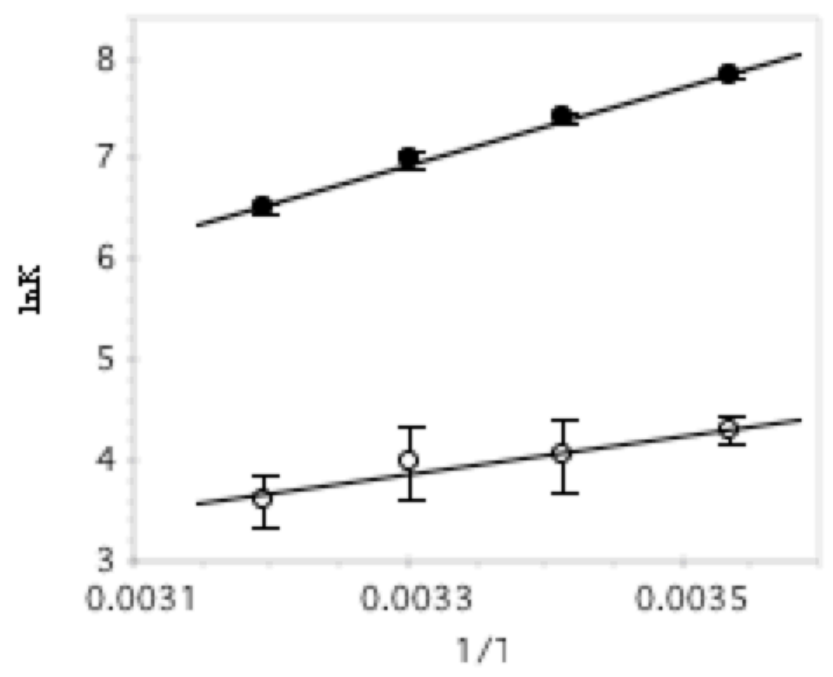

Figure 7. van't Hoff plot for EHUT in $\mathrm{CHCl}_{3}$.

Influence of temperature. As explained in part 3, the present method cannot be used to determine $\Delta \mathrm{H}_{2}$ directly. Consequently, measurements at several temperatures were performed in order to see if a van't Hoff analysis of the temperature variation of $\mathrm{K}_{2}$ could yield an estimate of $\Delta \mathrm{H}_{2}$. Figure 6 shows the enthalpograms obtained between 10 and $40^{\circ} \mathrm{C}$, when the same $12 \mathrm{mM}$ EHUT solution in chloroform is diluted into pure chloroform. The shift of the curves to higher concentrations is indicative of a decrease 
of the association constant $(\mathrm{K})$ with increasing temperature. The fit, which was performed at each temperature simultaneously on at least 4 experiments, yielded the values listed in Table 1. It can be seen that the same values are obtained at $20^{\circ} \mathrm{C}$ in $\mathrm{CDCl}_{3}$ and $\mathrm{CHCl}_{3}$. In order to comment the other experiments, it is more informative to consider the values of $\mathrm{K} / \mathrm{K}_{2}$, which is a measure of the cooperativity of the association; and $\mathrm{K}^{2} / \mathrm{K}_{2}$, which is the association constant between 2 oligomers. ${ }^{23} \mathrm{~K}^{2} / \mathrm{K}_{2}$ is more relevant than $\mathrm{K}_{2}$ or $\mathrm{K}$ in the high concentration regime where the chains are long. ${ }^{23}$ There is not only a clear decrease in $\mathrm{K}^{2} / \mathrm{K}_{2}$ with increasing temperature (the strength of the association is divided by 2 when the temperature is increased by $10^{\circ} \mathrm{C}$ ), but the cooperativity is also reduced. The van't Hoff plot (Figure 7) also shows the smooth variation of $\mathrm{K}_{2}$ and $\mathrm{K}$. The slope of the straight lines affords the corresponding enthalpy of association: $\Delta \mathrm{H}_{v \mathrm{H}}=-32 \mathrm{~kJ} \mathrm{~mol}^{-1}$ and $\Delta \mathrm{H}_{2 \mathrm{HH}}=-16 \mathrm{~kJ} \mathrm{~mol}^{-1}$. The first value is in perfect agreement with the values directly determined at each temperature (Table 1), which further validates our approach. Concerning $\Delta \mathrm{H}_{2 \mathrm{H}}$, the low value obtained is reasonable, considering the fact that $\mathrm{K}_{2}<\mathrm{K}$.

Influence of solvent. In order to test if this ITC procedure can be applied to more strongly associated systems, the dissociation of the same bis-urea supramolecular polymer was studied in toluene, where the association is known to be stronger than in chloroform, although no quantitative determination of the association has been reported. Figure 8 shows the heat flow measured during injection of a $1 \mathrm{mM}$ EHUT solution into toluene. This result is very similar to the data in $\mathrm{CDCl}_{3}$ (Figure 3), except that the signal intensity is an order of magnitude lower, because the concentration in the syringe had to be decreased, in order to obtain significant dissociation. The parameters of the model were determined by a simultaneous fit of 4 enthalpograms (Figure 9). The fit quality is satisfactory, although the lower signal to noise ratio (compared to Figure 5) is visible. It is worth mentioning that we had not previously been able to determine the association constant of this system (EHUT in toluene) by FTIR or NMR spectroscopy, thus showing the potential of ITC. The parameter values (Table 1) show that the association $\left(\mathrm{K}^{2} / \mathrm{K}_{2}\right)$ is 2 orders of magnitude stronger in toluene than in chloroform at the same temperature. This increase in strength goes together with an increase in cooperativity $\left(\mathrm{K} / \mathrm{K}_{2}\right)$ and enthalpy of association. 


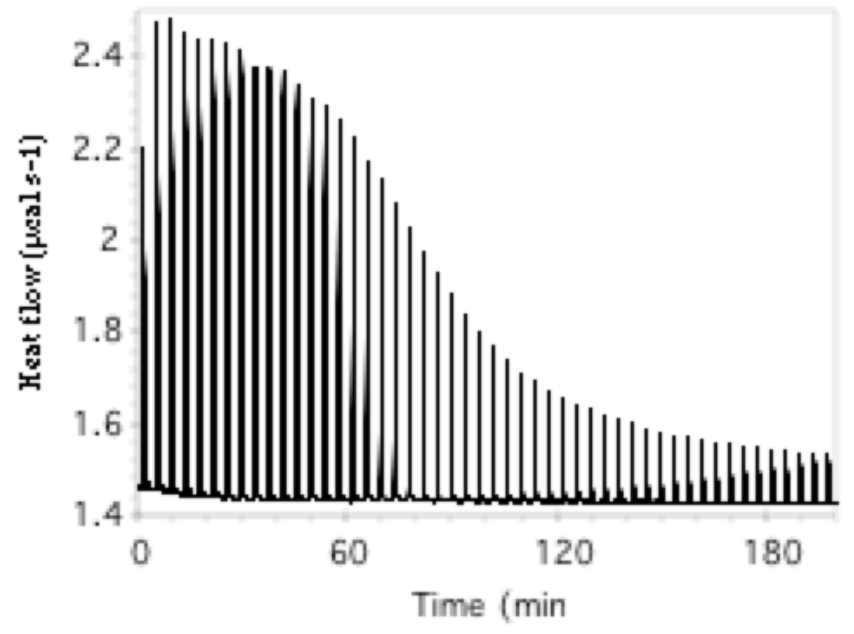

Figure 8. Heat effect produced by injecting $2 \mu \mathrm{L}$ aliquots of a $1 \mathrm{mM}$ EHUT solution in tolueneinto toluene $\left(\mathrm{T}=40^{\circ} \mathrm{C}\right)$.

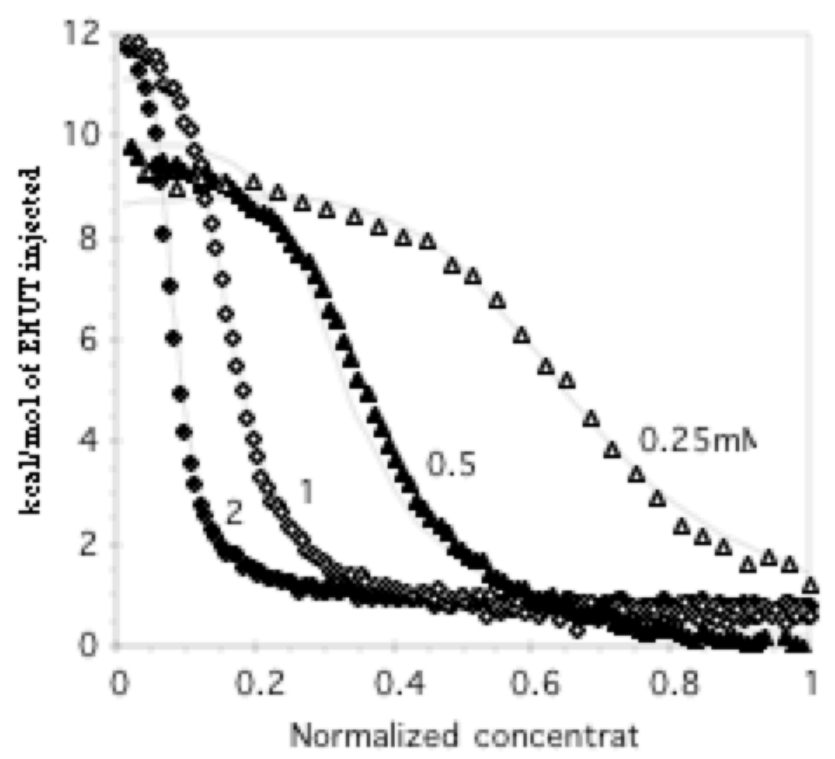

Figure 9. Enthalpograms of $2 \mathrm{mM}, 1 \mathrm{mM}, 0.5 \mathrm{mM}$ and $0.25 \mathrm{mM}$ EHUT solutions in toluene versus concentration normalized by the final cell concentration $\left(\mathrm{T}=40^{\circ} \mathrm{C}\right)$.

\section{Conclusion}


We have demonstrated that ITC is a powerful tool to characterize the self-association of supramolecular

polymers. Association constants in the range $10^{4}$ to $10^{6} \mathrm{dm}^{3} \mathrm{~mol}^{-1}$ have been successfully determined from the heat exchange occurring when a solution of supramolecular polymer is injected into the calorimetric cell containing pure solvent. Compared to other techniques (such as NMR or FTIR spectroscopy), the use of ITC presents several advantages: (i) the enthalpy of association is obtained together with the association constant from the same experiment, (ii) the measurements can be performed in almost any solvent, and (iii) systems with higher association constants can be characterized.

\section{References}

(1) Zimmerman, N.; Moore, J. S.; Zimmerman, S. C. Chem. Ind. 1998, 604-610.

(2) Supramolecular polymers; Ciferri, A., Ed.; Marcel Dekker, Inc.: New York, 2000.

(3) Brunsveld, L.; Folmer, B. J. B.; Meijer, E. W.; Sijbesma, R. P. Chem. Rev. 2001, 101, 4071-4097.

(4) Cifferi, A. J. Macromol. Sci., Polym. Rev. 2003, C43, 271-322.

(5) Sijbesma, R. P.; Beijer, F. H.; Brunsveld, L.; Folmer, B. J. B.; Hirschberg, J. H. K. K.; Lange, R. F. M.; Lowe, J. K. L.; Meijer, E. W. Science 1997, 278, 1601-1604.

(6) Castellano, R. K.; Clark, R.; Craig, S. L.; Nuckolls, C.; Rebek, J. Jr. Proc. Natl. Acad. Sci. U.S.A. 2000, 97, 12418-12421.

(7) Lortie, F.; Boileau, S.; Bouteiller, L.; Chassenieux, C.; Demé, B.; Ducouret, G.; Jalabert, M.; Lauprêtre, F.; Terech, P. Langmuir 2002, 18, 7218-7222.

(8) Söntjens, S. H. M.; Sijbesma, R. P.; van Genderen, M. H. P.; Meijer, E. W. J. Am. Chem. Soc. 2000, $122,7487-7493$.

(9) Castellano, R. K.; Craig, S. L.; Nuckolls, C.; Rebek, J. Jr. J. Am. Chem. Soc. 2000, 122, 7876-7882.

(10) Biocalorimetry, applications of Calorimetry in the Biological Sciences; Ladbury, J. E., Chowdhry, B. Z., Eds.; John Wiley \& Sons: Chichester, U.K., 1998.

(11) Blandamer, M. J.; Cullis, P. M.; Engberts, J. B. F. N. J. Chem. Soc., Faraday Trans. 1998, 94, 2261-2267. 
(12) Ross, P. D.; Rekharsky, M. V. Biophys. J. 1996, 71, 2144-2154.

(13) Zeng, H.; Miller, R. S.; Flowers, R. A.; Gong, B. J. Am. Chem. Soc. 2000, 122, 2635-2644.

(14) Lee, C.-H.; Na, H.-K.; Yoon, D.-W.; Won, D.-H.; Cho, W.-S.; Lynch, V. M.; Shevchuk, S. V.; Sessler, J. L. J. Am. Chem. Soc. 2003, 125, 7301-7306.

(15) Corbellini, F.; Di Costanzo, L.; Crego-Calama, M.; Geremia, S.; Reinhoudt, D. N. J. Am. Chem. Soc. 2003, 125, 9946-9947.

(16) Turnbull, W. B.; Daranas, A. H. J. Am. Chem. Soc. 2003, 125, 14859-14866.

(17) Bijma, K.; Engberts, J. B. F. N.; Blandamer, M. J.; Cullis, P. M.; Last, P. M.; Irlam, K. D.; Soldi, L. G. J. Chem. Soc., Faraday Trans. 1997, 93, 1579-1584.

(18) Dai, S.; Tam, K. C. Colloids Surf. A 2003, 229, 157-168.

(19) Raju, B. B.; Winnik, F. M.; Morishima, Y. Langmuir 2001, 17, 4416-4421.

(20) Heerklotz, H. H.; Binder, H.; Epand, R. M. Biophys. J. 1999, 76, 2606-2613.

(21) Blandamer, M. J.; Butt, M. D.; Cullis, P. M. Thermochim. Acta 1992, 211, 49-60.

(22) Boileau, S.; Bouteiller, L.; Lauprêtre, F.; Lortie, F. New J. Chem. 2000, 24, 845-848.

(23) Simic, V.; Bouteiller, L.; Jalabert, M. J. Am. Chem. Soc. 2003, 125, 13148-13154.

(24) Martin, R. B. Chem. Rev. 1996, 96, 3043-3064.

(25) Jadzyn, J.; Stockhausen, M.; Zywucki, B. J. Phys. Chem. 1987, 91, 754-757.

(26) Boileau, S.; Bouteiller, L.; Lortie, F. Chem. Eur. J. 2003, 9, 3008-3014.

(27) Arnaud, A.; Belleney, J.; Boué, F.; Bouteiller, L.; Carrot, G.; Wintgens, V. Angew. Chem. Int. Ed. Engl. 2004, 43, 1718-1721.

(28) ITC data analysis in Origin: Tutorial guide. MicroCal, 1998, p 73. 
For Table of Contents Use Only

\section{Isothermal titration calorimetry of supramolecular polymers}

Alix Arnaud, Laurent Bouteiller*
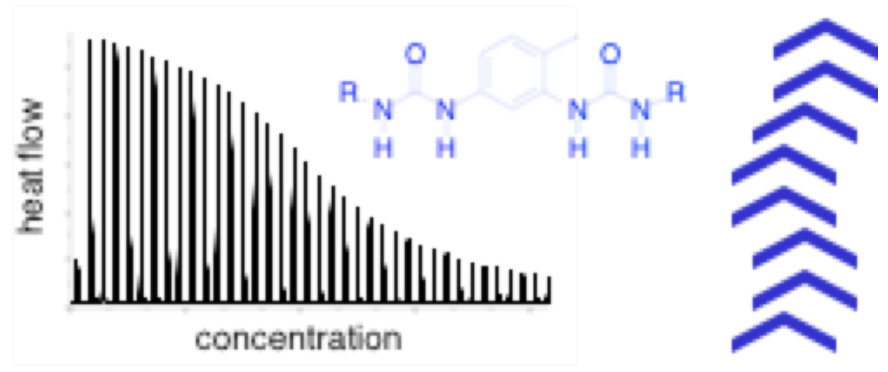